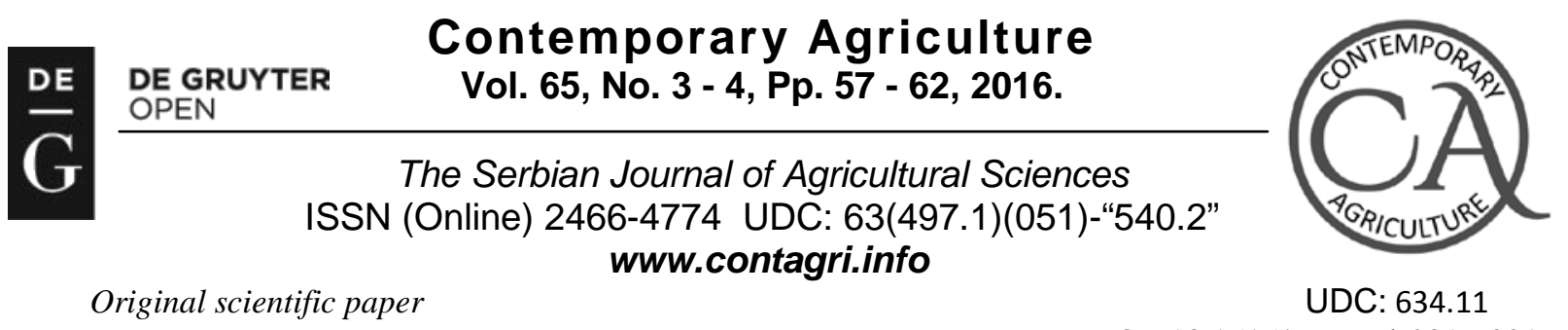

Original scientific paper

DOI: 10.1515/contagri-2016-0019

\title{
SUDDEN OCCURRENCE AND HARMFULNESS OF XYLEBORUS DISPAR (FABRICIUS) ON PEAR*
}

\author{
Snežana TANASKOVIĆ ${ }^{1 \star}$, Miloš MARJANOVIĆ1 , Sonja GVOZDENAC², \\ Nenad POPOVIĆ ${ }^{1}$, Goran DRAŠKOVIĆ ${ }^{1}$,
}

\begin{abstract}
Summary: Decline of pear trees in the region of Čačak (Serbia) is becoming a significant problem and a limiting factor in the production of this fruit species. This phenomenon may be due to the damages caused by xilophagous insects, representatives of the family Scolytidae. Economically the most important species of this family is a pear blight beetle (Xyleborus dispar), which causes symptoms of decline and/or wilting of pear trees. Such damages have not been documented so far in the region of Čačak. The aim of this study was to determine the cause of sudden appearance of pear trees decline in an orchard in this region (locality of Miokovci). The orchard has 180 trees (Stark Delicious, Santa Maria and Williams) in the sixth year of vegetation. Inspections were carried out every 30 days (20 April - 21 August 2016). Visual inspection identified X. dispar activity on 165 trees (about $92 \%$ of the trees in the orchard). Holes were registered on the trees up to a height of $160 \mathrm{~cm}$ and in all primary branches. The average number of entry openings on a random sample of 20 trees was 27 for the height from the soil surface to the first branch $(70 \mathrm{~cm})$, while it was 61 for the height up to $160 \mathrm{~cm}$. The recommended treatment is eradication of pests with mandatory incineration (burning) of the collected plant material by the end of February of the following growing season. This is the first report of $X$. dispar as pear pests in the vicinity of $\check{C} a c ̌ a k$.
\end{abstract}

Key words: Xyleborus dispar, pear, harmfulness, Čačak

\section{INTRODUCTION}

In natural ecosystems and agroecosystems, plants are often exposed to various forms of stress (Taiz and Zeiger, 2006). Most often, the stress is caused by an external factor which enhances the effect of different deficits on the plants (Taiz and Zeiger, 2006). Calculations indicate that because of the stress, the achieved crop yields in the open field are $22 \%$ of the genetic potential (Boyer, 1982). Insects are the primary or secondary pests in plant production. Xylophagous insects from the family Scolytidae are usually secondary pests of woody plants. In agriculture, the most important economic pests belonging to this family is a pear blight beetle or European shot-hole borer (Xyleborus dispar). Damages caused by this insect can lead to the decline of trees at a very high percentage (Tanasković et al., 2016), as well as the appearance of wilting symptoms, which lead to leaf abscission. This symptom is caused by hypoxia, which triggers the production of ethylene precursor (AAS) at the root xylem, which later spreads to the above ground parts of the plant (Taiz and Zeiger, 2006). Reaching the leaves, AAS oxidizes into ethylene. Some plants possess cells that rapidly multiply in conditions of elevated concentrations of ethylene, which results in the appearance of epinasty, causing the mentioned leaf abscission.

The main cause of pear blight beetle occurrence in orchards is the plant stress provoked by abiotic factors. The occurrence of late spring or early autumn frosts, drought periods, waterlogging caused by heavy rainfalls, soil pollution with heavy metals and hazardous substances are some of the factors that modify the physiological status of plants (Taiz and Zeiger, 2006). Also, flooding and poor soil drainage can provoke intolerant plants to become more susceptible to infestation by secondary pests (Ranger et al., 2016).

The aim of the research is to determine the cause of the sudden occurrence of pear trees decline, in an orchard in the vicinity of Čačak (locality of Miokovci). When the insect species causing the decline symptoms was determined,

\footnotetext{
${ }^{1}$ Snežana Tanasković, PhD, Assistant Professor, Miloš Marjanović, student, Nenad Popović, student, Goran Drašković, student, University in Kragujevac, Faculty of Agronomy in Čačak, Cara Dušana 34;32000 Čačak, Serbia. ${ }^{2}$ Sonja Gvozdenac PhD, Research Assistat, University in Novi Sad, Faculty of Agriculture, D. Obradovića 8, 21000 Novi Sad, Serbia.

*This research is a part of project supporting by Research resources of Faculty of Agronomy in Čačak

•Corresponding author: Snežana Tanasković, e-mail: stanasko@kg.ac.rs, Tel.:+381 32303400
} 
its biology and harmfulness were monitored in order to recommend the necessary measures for eradication of the infested plant material.

\section{MATERIAL AND METHODS}

Locality. The pear orchard is located in the village Miokovci, on the right bank of the river Čemernica. The

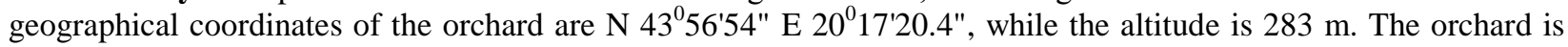
planted with 180 trees, out of which 177 trees are the variety Stark Delicious, two trees are the variety Santa Maria and one variety is Williams. All varieties were grafted on a quince rootstock MA. The plantation is in the sixth year of vegetation.

Time and frequency of field control. Field inspections were carried out every 30 days, starting from the first visit on $20^{\text {th }}$ April 2016. During each field activity, symptomatic trees were visually inspected, and insects and plant parts were collected, which is all documented in photographs. Inspections were carried out on $20^{\text {th }}$ April, $20^{\text {th }}$ May, $21^{\text {st }}$ June, $21^{\text {st }}$ July and $21^{\text {st }}$ August 2016.

Experimental protocol. During the first inspection of the orchard, on $20^{\text {th }}$ April 2016, the symptoms of a rapid decline of pear trees were recorded, and the holes, i.e. entry openings, on these trees were identified by visual inspections. The holes on the trunk were counted up to the first main branches. The height of the trees with the present holes was determined. Using fruit cutting equipment, parts of trees and branches with characteristic symptoms were cut off and collected in paper bags for further identification. At the entrance openings, the insects were captured and collected in a self-lock Ependorff tubes for identification.

Identification. Identification of the collected insect material was carried out according to Bright and Stark (1973) Determination Key, under the binoculars Leica M125 with LAS software system, at the Faculty of Agronomy in Čačak, Serbia.

Meteorological data. Meteorological data regarding the amount of rainfall and air temperature were obtained from the local weather station in Miokovci.

\section{RESULTS}

During the field inspection on $20^{\text {th }}$ April 2016, a uniformly modified habitus of pear trees in the orchard was registered. Changes were atypical and the trees looked like they were scalded (douched with hot water). Based on the general appearance, the symptom resembled the infection with bacterial fire blight caused by Erwinia amylovora, a disease well known to fruit producers. However, the symptoms differed from those of the bacterial infection in the absence of characteristic necrosis on the tips of the branches and on the flower buds. In a detailed inspection of trees, the symptoms of leaf and flower wilting were registered in the entire orchard.

Irregularly scattered round holes - about $2 \mathrm{~mm}$ in a diameter - were recorded on the trees, in the trunk zone and on the main branches. The openings on the surface of tree bark and branches were filled with a fine powder, similar to fine sawdust i.e. white frass trickles (Image 1a, b, c). The described changes were recorded on 165 trees, which account for $92 \%$ of the trees in the orchard.

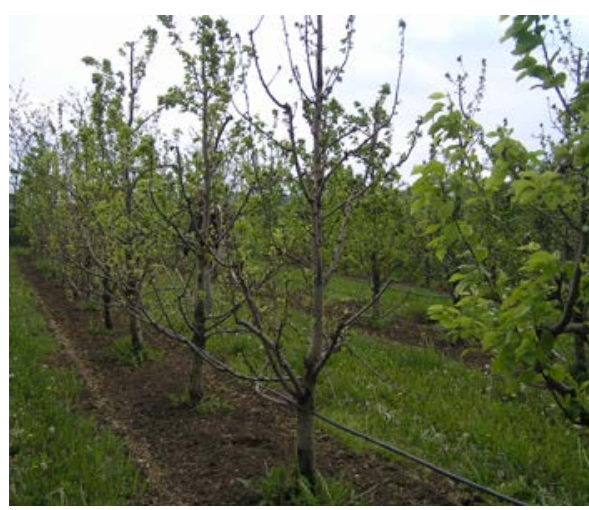

a)

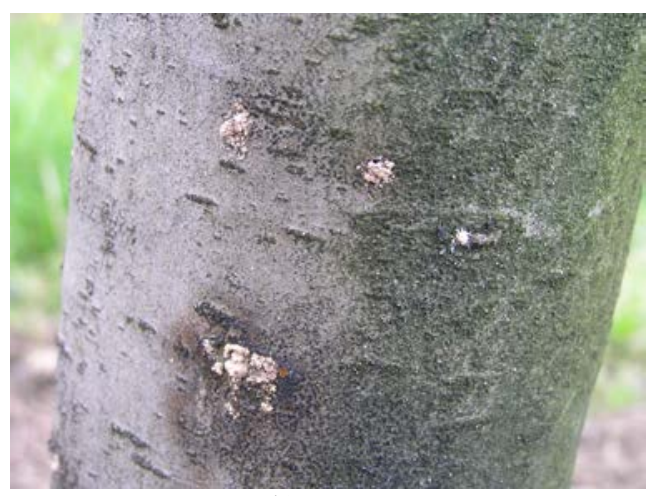

b)

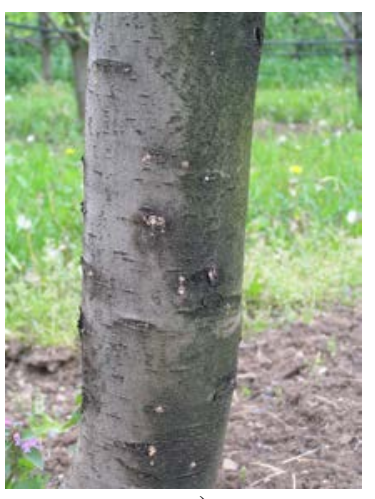

C)

Image 1a, $\boldsymbol{b}, \boldsymbol{c}$. Entry holes and white frass trickles (orig.)

Detailed counting of the number of openings on the trunk up to the height of the main branches $(65-70 \mathrm{~cm})$ indicates that it varied from 24 to 39 (Table 1). The average number of holes at this height was 27. During the 
inspection, the presence of openings along the tree trunk at the height of $160 \mathrm{~cm}$ was also registered. The openings were present at all thick branches up to the mentioned height. On the tree trunk, about $50 \%$ of the boring holes were positioned on the south-east side of the trees. The infested trees were divided into three categories based on the number of entry openings on the entire tree: trees with low infestation (up to 20 openings), trees with moderate infestation (35 openings) and trees with high infestation (more than 35 openings).

Round entry holes were discovered by incising the bark superficially at a boring position. They were set almost at the right angle to the central part of the trees (Image 2a, b). During the examination, the distal parts of the insects body were found in the holes (Image 3a, b, c), based on which it was concluded that the openings were the holes of a xylophagous species.

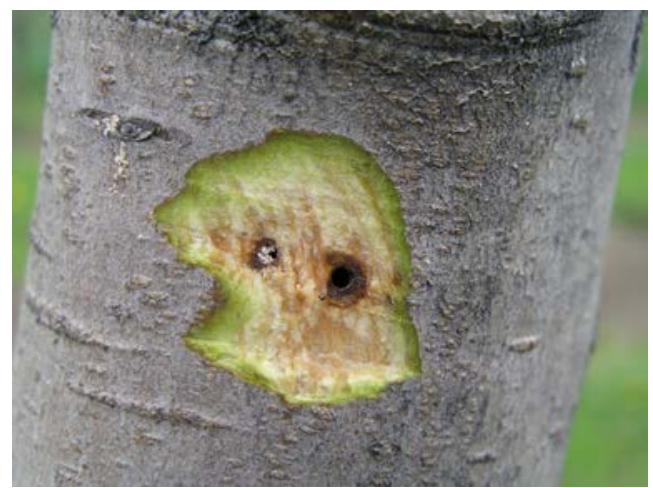

a)

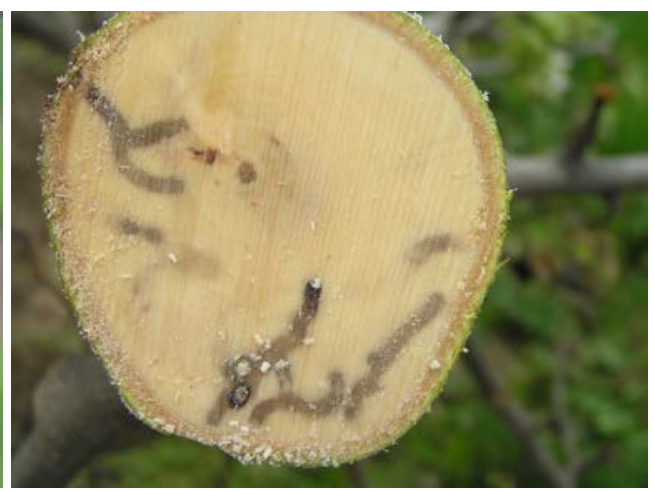

b)

Image $2 \boldsymbol{a}, \boldsymbol{b}$. Entry holes and a net of parental or breeding galleries (orig)

By cutting thinner and thicker branches in the zone of the insect holes on the transversal cut, a system of parental or breeding galleries characteristic for xylophagous insects was revealed (Image 4a, b, c).

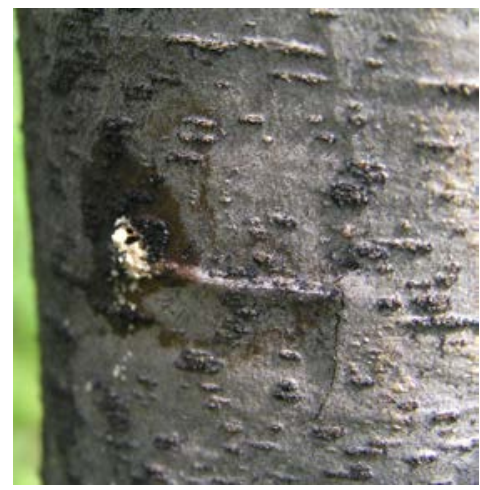

a)

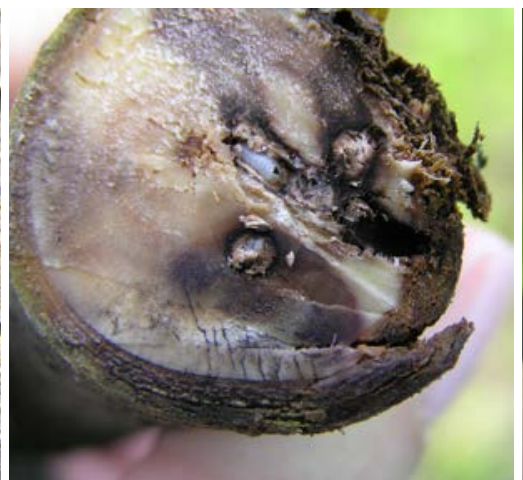

b)

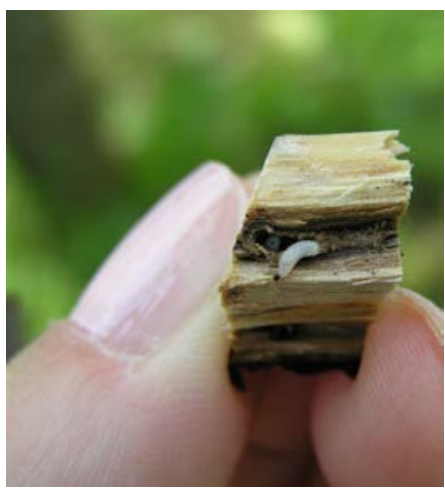

C)

Image 3a, $\boldsymbol{b}, \boldsymbol{c}$. Moist spots i.e. entry holes and larvae in parental galleries (orig)

In the Laboratory for Entomology at the Faculty of Agriculture in Čačak, all the basic morphological parameters of the collected insects were observed with the binoculars. Based on these, the species was identified as Xyleborus dispar, an autochthonous insect of European entomofauna, better known under the trivial names as a pear blight beetle and European shot-hole borer.

After identifying the pest species, and by using the knowledge on its biology and the effects of its presence, it was possible to determine the dynamics of field inspections and observations of changes in the infested orchard. Monitoring was carried out in 30-day intervals.

During the inspection on $20^{\text {th }}$ May 2016, physiologically stronger trees with fewer insect holes (Image 4a,b,c) continued further growth, fruit development and foliation. This is a result of applying intensive care measures, such as fertilization and irrigation, which helped the plants to overcome the stress caused by cutting the vascular system by insect holes. The intensive boring of parental galleries by females ended. The disruption of the vascular system also ended as a result of intensive nutrition and irrigation of orchards and by establishing normal physiological processes of plants growth and development, although there were occurrences of registered leakage of sap from insect holes (Image 4). 
During the first inspection (20 $0^{\text {th }}$ May 2016), the emergence of the larvae was registered. The larvae feed on the mycelial form of fungi Ambrosiella hartigii (mycetophagous) (Image 2b, 3b, c) in parental galleries, which are colored in dirty white to grey color, resulting from the development of fungus mycelium on the walls.

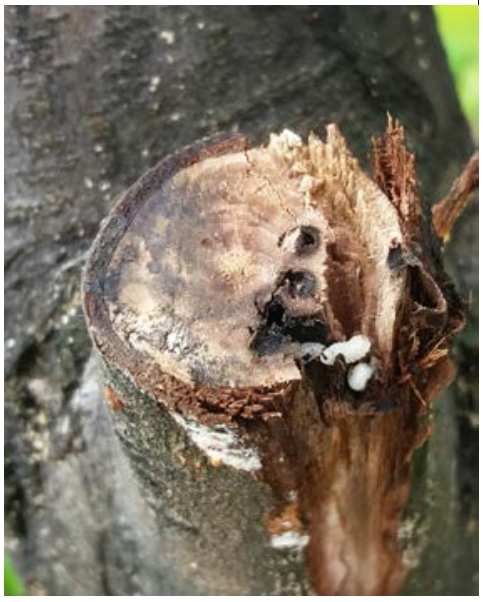

a)

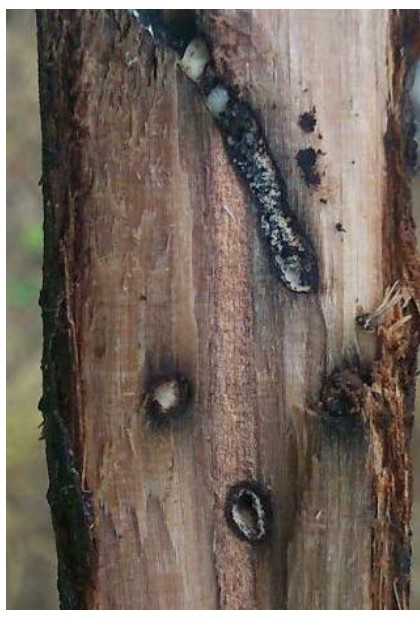

b)

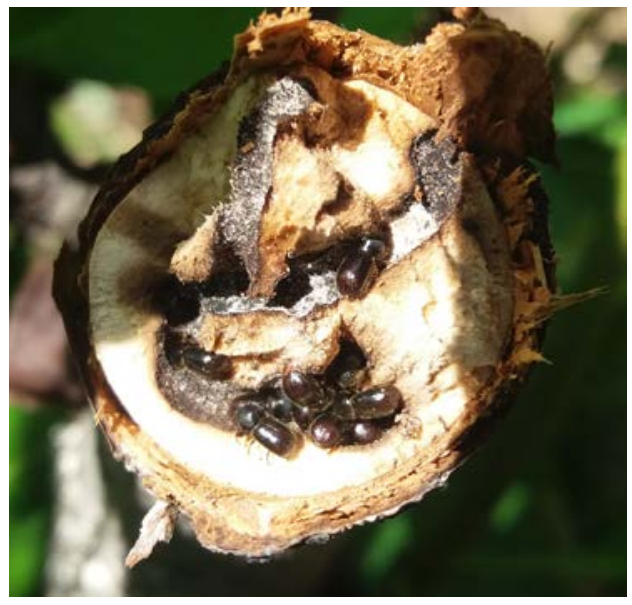

c)

Image 4a,b,c. Larvae, new generation imago and dark color of parental galleries (orig)

In the next field examination, carried out on $21^{\text {st }}$ June 2016, the plants were generally more exuberant compared to the previous field inspections. However, trees that had high level of infestation (over 35 entry openings) declined again and the fungus Schizophillum commune Fries was reported on them.

When cutting the branches in transversal cuts, the system of canals with larvae and adults of a new generation was present. The walls of the canals in which the insects completed their development were black. The change of color in the canals is the result of oxidation of the fungus A. hartigii mycelia (Krstić, 1961; Langendorf, 1961; Mirić, 2004).

During the fourth field inspection, on $21^{\text {st }}$ July 2016, a satisfactory general appearance of the trees was registered. The fruits were small in number but of exceptional quality and could be classified as extra and/or first class. The fungus Schizophillum commune continued its development on the declined trees, which caused massive bark cracking and separation of the bark from the tree. The insect galleries were densely filled with adult insects, which were preparing for the winter imaginal diapause (Image 4c).

The fifth and the final visual inspection prior to pear harvesting was on $21^{\text {st }}$ August 2016. Compared to the previous field observation, no significant differences in the overall appearance of the plants were recorded. Bark cracking and its separation from the woody parts was progressing on the declined trees. Insect activity was reduced to a minimum and only the presence of adults was registered. Larvae and pupae were absent. The given results indicate that the pest development cycle was completed.

\section{DISCUSSION}

Based on the observations and the collected data it can be concluded that the cause of this sudden decline of pear trees in the village Miokvci is a pear blight beetle - Xyleborus dispar. This insect is a secondary pest, a pest that infests weak plants that have a physiological disorder caused by different biotic and/or abiotic factors.

The infested pear orchard is located on the right water-front of the river Čemernica, which had two immense floodings during the vegetation seasons of 2014 and 2016. The river Čemernica flooded the orchard in the period $13^{\text {th }}-15^{\text {th }}$ May 2014. During this period, about $100.4 \mathrm{~mm}$ per $\mathrm{m}^{2}$ of rain precipitated, but without any adverse consequences to the trees in the orchard. A new incidence of flooding was registered on $7^{\text {th }}$ March in 2016. However, the water retreated from the orchard very slowly - in about twenty days. Three weeks after the flood, at the end of March 2016, the first changes on plants were registered, and these changes were later observed and studied during the vegetation period.

Soaking of the roots and removal of the top soil layer in this period had negative impact on the general physiological condition of the pear trees. Under such conditions, according to a number of authors, the plant responds by changing the chemical composition of specific volatile substances, so-called primary attractants and emits terpenic oil, such as alpha-pipen, delta-caren, limonene and camphene (Mihajlović, 2015), which attract xylophagous insects (Schowalter, 2013, Jozeyahan et al. 2015). In the spring, with increases in day and night 
temperatures, the females begin with flights and selection of a suitable host. With the system of senses (olfactory receptors) the female registers trees that emit these specific volatiles.

The infested pear orchard is located between two apple orchards. All three plantations were flooded during both years. However, in apple orchards the presence of a pear blight beetle was not recorded. This probably depended on grafting or how vigorous were the rootstocks on which the pears and apples were grafted. Pears were grafted on a quince rootstock MA, which is slightly stunted and has a shallow root system. This also results in high sensitivity to deficit or surplus of water in the root zone. Based on the obtained results, recommendation for the owner of the orchard is to carry out obligatory eradication of infested pear trees and incineration (burning) on the plant material by the end of February 2017.

In the older literature, it was reported that the activity of adult $X$. dispar begins when daily temperatures are increased at 18-20 ํㅡ. This usually coincides with the period of April and May (Schneider-Orelli, 1913, Schvester, 1954, Roediger, 1956, Egger, 1973, Mani and Schwaller, 1983, Mani et al. 1990, 1992, Schröder, 1996). However, the recent research indicates that adult flights begin when the maximum temperature reaches $14^{\circ} \mathrm{C}$ (Speranza et al., 2009). In central Italy, in the region of North Lazio, appearance of a pear blight beetle was investigated in a threeyear period. Monitoring was carried out with red sticky traps containing additional bottles with alcohol as an attractant. In this research it was found that the flights of this pest are in direct correlation with the amount of precipitation and temperature. During the rainy season, and lower temperatures, there are interruptions of the pest flights, but the flights are reactivated by improving weather conditions. Research from Lithuania in 2015 shows that the first flight of $X$. dispar in an apple orchard was registered at temperatures above $10{ }^{\circ} \mathrm{C}$. In Lithuanian conditions it is the beginning of April (Salmane et al., 2015). In Romania, the research indicates that the first flight was on $28^{\text {th }}$ of March in 2003, at temperature of $13.2{ }^{\circ} \mathrm{C}$ (Biociort and Marinescu, 2011). According to the available data, the emergence of adults in Serbia can be expected during March, depending on temperature conditions. Also, the registered grouping of adults of the new generation in parental galleries was recorded on $21^{\text {st }}$ July 2016, and is in accordance with the reports by Schvester (1954). The Agricultural Extension and Forecast Service in Serbia implemented phero traps in flight monitoring of a pear blight beetle during 2014-2016 period. The traps were placed at locations of Pirot, Leskovac, Šabac, Ruma, Jagodina and Užice. In monitoring in 2014 this pest was registered in the localities of Pirot and Užice, but in low numbers - maximum of 2 individuals / trap / day. In 2015 the locality of Užice was distinguished by three distinct peaks in the number of collected adult beetles: $12^{\text {th }}$ December (45 individuals), $19^{\text {th }}$ April (33 individuals) and $23^{\text {rd }}$ December (28 individuals). Apart from Užice, in 2015 a pear blight beetle was registered in Leskovac at three sites, with maximum of 6 individuals / trap / day. During monitoring activities in 2016, the specimens of $X$. dispar were also caught in the locality of Užice. Biofix was registered on $20^{\text {th }}$ March (2 individuals), afterwards there were three peaks in the number of the caught specimens on $28^{\text {th }}$ March (25 individuals), $30^{\text {th }}$ March (40 individuals) and $5^{\text {th }}$ April (101 individuals). A forecast monitoring system of the Agricultural Extension and Forecast Service of Serbia still have not placed traps for monitoring these pests on the territory of Čačak.

Monitoring of a pear blight beetle will continue in the next vegetation at the same localities, including the experimental orchard. When the vegetation starts in early March, the beginning of adult flight will be monitored with red sticky traps and bowls with alcohol. If necessary, we will recommend the application of adequate chemical measures for eradication of females in the orchard, to prevent appearance of boring holes that cause significant damages.

\section{CONCLUSION}

Monitoring the insects and the changes on the pear trees during 2016 indicates that: 1 . The cause of the sudden decline of 165 pear trees in the village Miokovci is $X$. dispar; 2 . Only female adult beetles are harmful, while larvae feed on mycelium of the fungus Ambrosiella hartigii (mycetophagous); 3. The average number of entry openings on the infested trees at the height up to $160 \mathrm{~cm}$ from the soil surface was $61 ; 4$. The presence of the first adults in holes was registered on $20^{\text {th }}$ March 2016, when females were at the beginning of oviposition; 5. The presence of the first larvae was recorded in the parental galleries, and the color of their walls did not differ from the color of the trees in the cross section during the inspection on $20^{\text {th }}$ May 2016; 6 . Adults of the new generation were identified in the inspection on $06^{\text {th }}$ June 2016, after which the trees with fewer holes continued vegetative development; 7. Preparation for winter imaginal diapause was registered on $21^{\text {st }}$ June 2016 with the presence of a large number of adults from the new generation in the maternal parental galleries with oxidized (dark brownish) content.

$X$. dispar monitoring will continue in the next growing season on the same locality, after the partial or complete eradication of orchards, which should be completed by February 2017.

\section{REFERENCES}


BOCIORT M and MARINESCU M: Research on controling Anisandrus dispar (Scolytidae) in orchard from Cărand Village, Arad, Romania. Studia Universitatis Vasile Goldis Seria Stiintele Vietii (Life Sciences Series), 21(4), 739-744, 2011.

BRIGHT DE JR and STARK RW: The bark and ambrosia beetles of california Coleoptera: Scolytidae and Platypodidae. Bulletin of the california insect survey, Vol XVI, 1973. ISBN 0520-09480-8

EGGER A: Beiträge zur Biologie und Bekämpfung von Xyleborus (Anisandrus) dispar F. und X. saxeseni Ratz. (Col., Scolytidae). Anzeiger für Schadlingskunde, Pflanzen- und Umweltschutz, 46(12):183-186, 1973.

JOZEYAHA A, VAFAEI SHOUSHTARI R, ASKARY H: Oaks wood borer beetle and relationship with dryness oak trees in ilam province. Trends in life sciences, 4(4): 273-280, 2015.

MANI E and SCHWALLER F: Zur Flugüberwachung und Bekämpfung des Ungleichen Holzbohrers, Xyleborus (Anisandrus) dispar F. Schweizerische Zeitschrift für Obst- und Weinbau, 119:104-108, 1983.

MANI E, REMUND U, SCHWALLER F: Attack of the bark beetle, Xyleborus dispar F., (Coleoptera: Scolytidae) in orchards and vineyards. Importance, biology, flight observations, control, development and use of an efficient ethanol trap. Acta Phytopathologica et Entomologica Hungarica, 27(1-4):425-433, 1992.

MANI E, REMUND U, SCHWALLER F: The bark beetle, Xyleborus dispar F. (Coleoptera: Scolytidae) in fruit- and vine-growing. Importance, biology, control, development and use of an efficient ethanol trap, flight observations. Landwirtschaft Schweiz, 3(3):105112, 1990.

MIHAJLOVIĆ LJ: Šumarska entomologija. Šumarski fakultet Beograd, Univerzitet u Beogradu, pp. 1-925, 2015.

RANGER CM, REDING ME, SCHULTZ PB, OLIVER JB, FRANK SD, ADDESSO KM, HONG CHONG J, SAMPSON B, WERLE C, GILL S, KRAUSE C: Biology, Ecology, and Management of Nonnative Ambrosia Beetles (Coleoptera: Curculionidae: Scolytinae) in Ornamental Plant Nurseries. Journal of Integrated Pest Management, 7(1):9, 1-23, 2016. FD Oxford University Press, DOI 10.1093/jipm/pmw005

ROEDIGER H: Zur Biologie und Bekämpfung des Ungleichen Holzbohrers (Xyleborus dispar F.). Nachrichtenblatt für den Deutschen Pflanzenschutzdienst, 8:36-40, 1956.

SALMANE I, CIEMATNIEKS R, OZOLINNA-POLE L, RALLE B, IEVINSH G: Investigation of European shot-hole borer, Xyleborus dispar (Coleoptera, Scolytidae), in apple orchards of Latvia. Environment. Technology. Resources, Proceedings of the 10th International Scientific and Practical Conference, Rezekne, Latvia, 18-20. June. Volume II, pp. 256-260, 2015.

SCHNEIDER-ORELLI O: Untersuchungen über den pilzzüchtenden Obstbaumborkenkäfer Xyleborus (Anisandrus) dispar und seinen Nährpilz. Centralblatt für Bakteriologie und Parasitenkunde, 38:25-110, 1913.

SCHOWALTER T: Insects and Sustainability of Ecosystem Services, CRC Press, pp. 23-45, 2013.

SCHRÖDER WO: Ungleicher Holzbohrer und kleiner Holzbohrer. Rheinische Monatsschrift, 1:13-15, 1996.

SCHVESTER D: Le Xylébore disparate, Anisandrus dispar F. (Coléoptere Scolytide) en France. Annales des Epiphyties, Serie C, 5:225-257, 1954.

SPERANZA S, BUCINI D and PAPARATTI B: New Observation on Biology of European Shot-Hole Borer [Xyleborus dispar (F.)] on Hazel in Northern Latium (Central Italy). Acta Hort. 845, 539-542, 2009.

TAIZ L and ZEIGER E: Plant physiology, 4th edition, pp. 1-764, 2006. Sinauer associates.

TANASKOVIĆ S, MARJANOVIĆ M, DRAŠKOVIĆ G, POPOVIĆ N: Pojava Xyleborus dispar na krušci u okolini Čačka. 15. Kongres voćara i vinogradara Srbije sa međunarodnim učešćem, Kragujevac, Srbija, 21-23. Septembar, Zbornik apstrakta, pp. 288, 2016.

\section{IZNENADNA POJAVA I ŠTETNOST XYLEBORUS DISPAR (FABRICIUS) NA KRUŠCI}

Izvod: Sušenje stabala kruške u regionu Čačka (Srbija) predStavlja značajan problem i ograničavajući faktor u proizvodnji ove voćne vrste. Uzroci ove pojave mogu biti i ksilofagi insekti iz porodice Scolytidae, a ekonomski najznačajnija vrsta ove porodice je voćni sipac (Xyleborus dispar). Štete od ovog insekta mogu prouzrokovati pojavu prosušivanja i/ili sušenja stabala kruške, koja nisu dokumentovana do sada (nema pisanih podataka). Cilj istraživanja bio je da se utvrdi uzrok iznenadne pojave prosušivanja zasada krušaka u okolini Čačka (lokalitet Miokovci - N43056'54", E20017'20,4", nadmorska visina 283 m). Zasad je u šestoj godini starosti, a u njemu se nalazi 180 stabala sorti Starkov delišes, Santa Marija i Vilijamovka. Vizuelni pregledi obavljeni su u intervalu od 30 dana, počev od 20. aprila do 21. avgusta 2016. godine. Prvim i svakim sledećim terenskim izlaskom registrovane su nastale promene na, i unutar infestiranih biljaka. Vizuelnim pregledom utvrđeni su tragovi aktivnosti $X$. dispar na 165 stabala, ili na oko 92\% stabala. Ubušenja su registrovana na stablu do $160 \mathrm{~cm}$ visine i na svim primarnim granama. Prosečan broj ulaznih otvora, na slučajnom uzorku od 20 stabala, na visini do prve ramene grane $(70 \mathrm{~cm})$ iznosio je 27 . Prosečan broj od 61 ubušenja utvrđen je na visini stabla do $160 \mathrm{~cm}$ od površine zemljišta. Obavezna mera postupanja je eradikacija štetočine i obavezna insineracija (spaljivanje) biljnog materijala, najkasnije do kraja februara naredne vegetacije. Ovo je prvi nalaz $X$. dispar kao štetočine kruške u okolini Čačka.

Ključne reči: Xyleborus dispar, kruška, štetnost, Čačak

Received / Primljen: 15.10.2016.

Accepted / Prihvaćen: 03.12.2016. 